\title{
Isolation of Phosphate Solubilizing Microorganism (PSM) from Reclaimed Fly Ash Zone of Mejia Thermal Power Station (MTPS) and its Implications
}

\author{
Upasana Datta ${ }^{1}$, Bishakha Mondal ${ }^{2}$ and Abhijit Mitra ${ }^{3}$ \\ Faculty of Microbiology, Department of Oceanography, Techno India University, Salt Lake Campus, Kolkata, India ${ }^{1}$ \\ Student B.Tech Biotechnology, Dept. of Biotechnology, Techno India University, Salt Lake Campus, Kolkata, India ${ }^{2}$ \\ Faculty of Marine Science, Department of Marine Science, University of Calcutta, Kolkata, India ${ }^{3}$
}

\begin{abstract}
The present world is greatly inclined towards alternating energy, but yet the use of coal as a primary energy source cannot be avoided. Disposal of huge amount of fly ash from the thermal power plants cannot be bypassed, since we cannot circumvent the second law of thermodynamics. The management of fly ash is a matter of great concern, in the present century. It has great potentiality in agriculture due to its efficacy in modification of soil health and crop performance. The present paper aims to highlight the optimum use of the metal phosphorus, present in the fly ash generated from Mejia Thermal Power Station (M.T.P.S), in boosting the agricultural production. The paper also identified strains of Phosphorus Solubilizing Bacteria (PSB's) that are capable of converting the insoluble form of phosphorus present in rock soil into a more accessible soluble form.
\end{abstract}

Keywords: Phosphate solubilizing bacteria (PSB), Reclaimed site, Phosphate amendment, Fly Ash (FA), Mejia Thermal Power Station (MTPS), Phosphate solubilization, Tricalcium phosphate, Organic acids.

\section{INTRODUCTION}

Fly Ash (FA), also termed as "fuel ash", is the end product green leaf formation which escalates to red pigmentation residue of pulverized bituminous and sub-bituminous coal in leaf bases ultimately . Studies also inform that combustion of TPPs, accounted for the partial combustion differentially expressed mRNA transcripts provide of coal minerals and it houses a bulk quantity of mineral intuition into the long term responses of plants [3] elements [1]. There are many factors responsible for the Diagnosing the deficiency of phosphorus is a challenging chemical bed make-up of FA, and a thorough study of 11 work and by the time it gets discovered, recovery is no FAs from different power plants of the U.S. [2] , more an option. [4]

established that the major constituents of FA happens to be $\mathrm{Al}, \mathrm{Fe}$ and $\mathrm{Si}$, along with very small concentrations of $\mathrm{Na}$, $\mathrm{Ca}, \mathrm{K}, \mathrm{S}$ and Ti. Apart from this, FA also accommodates a rich quantum of essential macronutrients like $\mathrm{P}, \mathrm{K}, \mathrm{Ca}, \mathrm{S}$ and $\mathrm{Mg}$; while micronutrients like $\mathrm{Fe}, \mathrm{Mn}, \mathrm{Zn}, \mathrm{As}, \mathrm{Pb}, \mathrm{Co}$, $\mathrm{Cu}$, Mo and $\mathrm{B}$ are present in trace amounts.

Plants uptake these mineral elements in several durations of their growth phase, to meet their daily growth requirements for sustenance and thriving, and for maintaining mineral and water balance as well as for protection against various pests and diseases. The mineral Phosphorus (P) is one such crucial element present in plants that holds a prime position in restoring plant health and homeostatis. Mainly present in the form of phosphates and phospholipids, phosphorus is a major component of DNA, RNA, ATP as well as the cellular membranes, thereby demonstrating its link between life and living forms. Apart from its innumerous contributions towards plant growth accounting to root extension, stem and stalk strength, fruit and flower production, and disease resistance abilities, a few major problems linked with phosphorus deficiency in plants prominently are stunted growth, deficiency symptoms resulting in dull greyish-

Plants are unable to uptake insoluble phosphorus but acquire phosphorus only in soluble form as a phosphate anion. In recent years, researches showed that certain microbial strains (especially those associated with plant rhizosphere) have the ability to utilize beneficiary elements present in the soil, initiating plant growth [5]. The group of microorganisms which bear the potential to hydrolyze organic and inorganic phosphorus from insoluble compounds into simpler soluble forms are referred to as Phosphate Solubilizing Microorganisms (PSMs). Therefore PSMs can be used as bio fertilizer amendments and inoculums of the microbial strains upon implementation can help in achieving crop improvement [6-10]. Many agriculturalists of the current era are attracted to the possibility and several researches have been in focus for the last decade [11 - 13]. These microbial strains broadly fall in the category of "plant growth promoting rhizobacters" (PGPRs) [14] comprising the genera of Pseudomonas, Azospirillum, Bacillus, Enterobacter, Burkholderia, Rhizobium, Serratia, Acinetobacter, Flavobacter, Erwinia and Arthrobacter.

The element phosphorus is a highly unstable and reactive element. Being one of the major nutrient present in FA, an 
addition of FA amended fertilizer to soil readily causes an oxidation reaction, immediately imparting soluble phosphorus to the soil increasing soil fertility. However, when large portions of insoluble phosphate are applied to soil in the form of chemical fertilizers, it is immobilized rapidly and becomes unavailable to the plants [15].

Phosphate solubilization by PSB strain is associated with the release of low molecular weight organic acids, which causes their hydroxyl and carboxyl group to chelate the unwanted cations bound with phosphate converting it from insoluble form to soluble form [16-18]. The process is followed by the release of organic acids such as glycolic, oxalic, malonic and succinic acid into the surrounding media by the PGPR strains, most of which have been reported to have efficient phosphorus solubilizing ability [19]. In addition to this, PSB strains releases inorganic acids like sulphidric, carbonic and nitric acid, which further act as a chelating agent thus transferring $\mathrm{P}$ into soluble form for the easy utilization of crops [20 - 23]. Thus there exists a distinct correlation between $\mathrm{pH}$ and the amount of phosphorus solubilized [24, 25, 26]. Some PSB strains are also known to generate the enzyme phytase which efficiently hydrolyses organic phosphates.

Fly-ash holds a great potential in the field of agriculture due to its high porosity, low particulate diameter, water retention capacity and availability of major macro and micro nutrients like P, K, Ca, etc., that helps to modify soil health and upsurges crop production. Many researchers have conducted innovative works in the past, to demonstrate the useful impact of fly-ash in soil, agriculture and in forestry [27, 28].

Researches have also, showed an upsurge in crop production after the application of PSB in fly-ash, for crops such as maize, wheat, lentil, soya bean, cabbage, cucumber, tomato and potato [29]. This can be accounted from the presence of a variety of utility trace elements in fly ash namely, $\mathrm{P}, \mathrm{Na}, \mathrm{K}, \mathrm{Fe}, \mathrm{Zn}$ and $\mathrm{Ca}$ that act as good source of micronutrients for growing plants, however the presence of many biologically toxic elements such as B, Mo and S in FA cannot be ignored altogether [30]. This problem can be mitigated to some extent, by lowering down the level of toxic trace elements consecutively increasing the availability potency of useful elements like Phosphorus and Potassium present in it. The application of PSM inoculants can alter the biological content of the ash, stimulating the conversion of insoluble phosphorus into soluble form, therefore simultaneously improving crop fertility and increasing $\mathrm{P}$ bioavailability.

\section{MATERIALS AND METHODS}

\section{A. Collection of Samples}

1. Sample site description: The entire research area, included the two FA ponds - FA pond I and FA Pond II; lying adjacent to each other and in the close vicinity of the MTPS power plant $\left(23^{\circ} 26^{\prime} 39.6^{\prime \prime} \mathrm{N}\right.$ and $\left.87^{\circ} 07^{\prime} 48.2^{\prime \prime} \mathrm{E}\right)$ which falls under the Survey of India Topo Sheet No. 73 $\mathrm{M} / 3$. The MTPS power plant, falls in Bankura district of West Bengal (35 Km by road from Durgapur), surrounded by the Latiabani village to the north, Baghdaha village to the south, SH-5 towards the west and Radhakrishnapur village towards the east.

The FA Pond I - is the FA dump area, containing a slurry mixture of Dry FA (from the Power plant) and water (from the river Damodar).

FA pond II - represents the reclaimed FA dump site that emerged to a converted forest land ( $\sim 50$ Hectare) through years of bioremediation practices.

Originally both Ponds were replica models of one another.

\section{Types of Sample:}

The FA samples were collected from the power plant, the pond ash bed and the reclaimed study site; accordingly being categorized into the following 3groups:-

a) Dry Fly Ash (DFA) - It constitutes the sterile dry piping hot FA, and was collected from the power plant chimney, and transported through vacuum powered pipelines onto the field site.

b) Settled Fly Ash (SFA) - It constitutes the FA slurry formed by the rigorous mixing of the FA (from chimney) with the water (Damodar river), carried to the field by slurry pipelines. It was collected from FA Pond I after months of FA slurry settled in it.

c) Reclaimed Fly Ash (RFA) - It constitutes the FA from FA Pond II study site, after 10 years of plantation program and afforestation, conducted on the ash bed. The aforesaid sample was collected from the rhizosphere of a planted tree, namely Acacia auriculiformis, which was $\sim 10$ years old, on the day of collection.

\section{B. Isolation of PSM / PSB from Fly Ash}

1. Procedure:

To extract bacteria from FA obtained from each of the above study sites, $0.5 \mathrm{~g}$ of each of the sample was mixed with $50 \mathrm{~mL}$ of sterile $0.2 \% \mathrm{NaCl}$ solution ( fly ash : solution $=1: 100$, w:v) in $3100 \mathrm{ml}$ conical flasks and each shaken for $16 \mathrm{~h}$ in a rotating shaker[31]

\section{Preparation of Medium:}

The first isolation procedure of PSM was performed using "National Botanical Research Institute's phosphate (NBRIP) medium" containing (per L) $10 \mathrm{~g}$ glucose, $5 \mathrm{~g}$ $\mathrm{Ca} 3(\mathrm{PO} 4) 2,5 \mathrm{~g} \mathrm{MgCl} 2 \cdot 6 \mathrm{H} 2 \mathrm{O}, 0.25 \mathrm{~g} \mathrm{MgSO} 4 \cdot 7 \mathrm{H} 2 \mathrm{O}, 0.2$

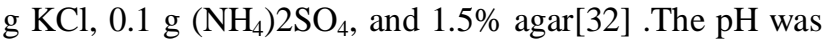
adjusted to $\sim 7.0$ after mixing all the media ingredients to water but before the addition of agar.

The second PSM isolation process was carried out using our own "Modified Phosphate Media (MPM)" amended by Upasana Datta and Abhijit Mitra, which bears certain alterations to the former, to try and attain better growth and a clearer perception as it bore less precipitate specks upon it, thereby aiding in an accurate colony count.

The colonies formed on the culture plates with clear halos, after a 7 day incubation period, were duly noted and considered as PSMs [33].

The composition of the NBRIP medium and the "Modified Phosphate Medium" is given below in Table -1 and Table2 respectively. 
TABLE-1: NBRIP MEDIUM [NATIONAL BOTANICAL RESEARCH INSTITUTES PHOSPHATE MEDIUM]

\begin{tabular}{|c|c|}
\hline S.NO & Ingredients \\
\hline 1. & Dextrose \\
\hline 2. & $\mathrm{Ca}_{3}\left(\mathrm{PO}_{4}\right)_{2}$ \\
\hline 3. & $\mathrm{MgCl}_{2} \cdot 6 \mathrm{H}_{2} \mathrm{O}$ \\
\hline 4. & $\mathrm{MgSO}_{4} \cdot 7 \mathrm{H}_{2} \mathrm{O}$ \\
\hline 5. & $\mathrm{KCl}$ \\
\hline 6. & $\left(\mathrm{NH}_{4}\right)_{2} \mathrm{SO}_{4}$ \\
\hline 7. & Agar \\
\hline \multicolumn{2}{|c|}{$\mathrm{pH}=7.2 \pm 0.2$} \\
\hline
\end{tabular}

TABLE-2: MPM [MODIFIED PHOSPHATE MEDIUM]

\begin{tabular}{|c|c|}
\hline S.NO & Ingredients \\
\hline 1. & Dextrose \\
\hline 2. & $\mathrm{Ca}_{3}\left(\mathrm{PO}_{4}\right)_{2}$ \\
\hline 3. & $\mathrm{MgSO}_{4} \cdot 7 \mathrm{H}_{2} \mathrm{O}$ \\
\hline 4. & $\mathrm{KCl}$ \\
\hline 5. & $\left(\mathrm{NH}_{4}\right)_{2} \mathrm{SO}_{4}$ \\
\hline 6. & $\mathrm{MnSO}_{4} \cdot 2 \mathrm{H}_{2} \mathrm{O}$ \\
\hline 7. & $\mathrm{FeSO}_{4} \cdot 7 \mathrm{H}_{2} \mathrm{O}$ \\
\hline 8. & $\mathrm{Agar}$ \\
\hline \multicolumn{2}{|c|}{$\mathrm{pH}=7.2 \pm 0.2$} \\
\hline
\end{tabular}

Both media may serve as a Selective media for the isolation of PSMs as per convenience and nature of study.

\section{Isolation of PSM:}

After a $16 \mathrm{~h}$ sub culturing procedure, the PSMs were isolated from each sample either by spread plate method or by serial dilution method. Both the processes are discussed below

\section{Spread Plate Method -}

1 milliliter $(1 \mathrm{ml})$ and 500 microliter $(500 \mu \mathrm{l})$ of supernatant from one of the 3 samples was spread on two culture plates separately, each containing phosphate medium (hardened and cooled prior to it) in the LAF (Laminar Air Flow Hood) and incubated at $27-30^{\circ} \mathrm{C}$ for 7 days. Similar process was repeated for the other 2 types of sample individually.

Serial Dilution Method -

1 milliliter $(1 \mathrm{ml})$ of supernatant from each of the 3 sample types was dispersed in $9 \mathrm{ml}$ of autoclaved distilled water and was thoroughly vortexed. $1 \mathrm{ml}$ of the above solution was again transferred to $9 \mathrm{ml}$ of sterile distilled water to form $10^{-2}$ dilution. This was followed 6 more times to get $10^{-3}, 10^{-4}, 10^{-5}, 10^{-6}, 10^{-7}$ and $10^{-8}$ serials respectively, for each type sample. 500 microliter $(500 \mu \mathrm{l})$ of each dilution was spread on phosphate medium containing insoluble tricalcium phosphate and incubated at $27-30^{\circ} \mathrm{C}$ for 7 days. Colonies showing halo zones were isolated and purified 5 times by subculture method on each of the aforementioned phosphate agar medium for studying colony morphology [34].

\section{Checking of $\mathrm{pH}$ and its Methodology:}

A broth culture was made, following the MPM composition; and $1 \mathrm{ml}$ of supernatant (from $16 \mathrm{~h}$ rotation and subculture of $1 \mathrm{~g}$ sample added to $50 \mathrm{ml}$ of $0.2 \% \mathrm{NaCl}$ solution) of each of the 3 Types of FA collected was added to $50 \mathrm{ml}$ of culture broth, each taken in a100 $\mathrm{ml}$ conical flasks separately. The broth was then allowed to rotate for a $72 \mathrm{~h}$ time duration in an end-over-end shaker, under aseptic conditions [33]

Analysis of $\mathrm{pH}$ of the Supernatant -

The $\mathrm{pH}$ of the supernatants from each of the 3 FA sample, were then tested separately.

Elico $\mathrm{pH}$ meter

The $\mathrm{pH}$ of the selected supernatant was recorded with a portable Elico $\mathrm{pH}$ meter [35]

\section{Gram Staining:}

The isolates obtained were passed through a standard gram staining procedure to detect their individual characteristic - of whether they are gram positive or gram negative in nature. [36]. The Bacterial smear was heat fixed onto a glass slide with the help of an inoculating loop and air dried. A 30 second time gap was maintained after addition of crystal violet stain followed by a distilled water wash. After drying grams iodine was added for the next 60 seconds. This was consecutively washed with $95 \%$ ethyl alcohol and saffranin was added for the next 30 seconds, till it was washed-off with distilled water. After air drying or blot drying of the smear the colonies were observed under a microscope. While pink colonies will show the gram negative characteristic of the bacterial colony, the purple colonies confirms the presence of a gram positive strain.

\section{Morphology :}

Morphological characteristics of the isolates found growing on the culture plates viz. shape, size, elevation, colony structure, surface form, margins and surface texture or color; at $10^{-4}, 10^{-6}$ or $10^{-8}$ dilution spreading were noted down and observed for their characterization. [37]

\section{RESULTS}

\section{A. Isolation of PSB / PSM}

\section{Using NBRIP medium:}

Liquid Broth Culture - After a rotating period of 72 days, the flasks containing $1 \mathrm{~g}$ of sample each from SFA, DFA and RFA were taken down and following was observed:-

The supernatant in the flasks had become turbid cloudy white in coloration.

Several flocculent cotton like clusters formed at the bottom of all flasks, which increased consecutively, with each passing day and in proportion to the bacterial count in the broth.

Solid Plate Culture - The colony growth pattern is clearly visible from the underlying graphs:

\section{B. Morphology}

All the samples showed luxurious growth of a myriad of colonies. However PSMs sported morphological features like white colonies often growing isolated from the rest and forming a clear "halo" zone as a result of calcium tri 
phosphate solubilization [38]. The radii of the "halo" increased gradually, with the increased number of days $-\mathrm{a}$ clear indication of increasing colony size.

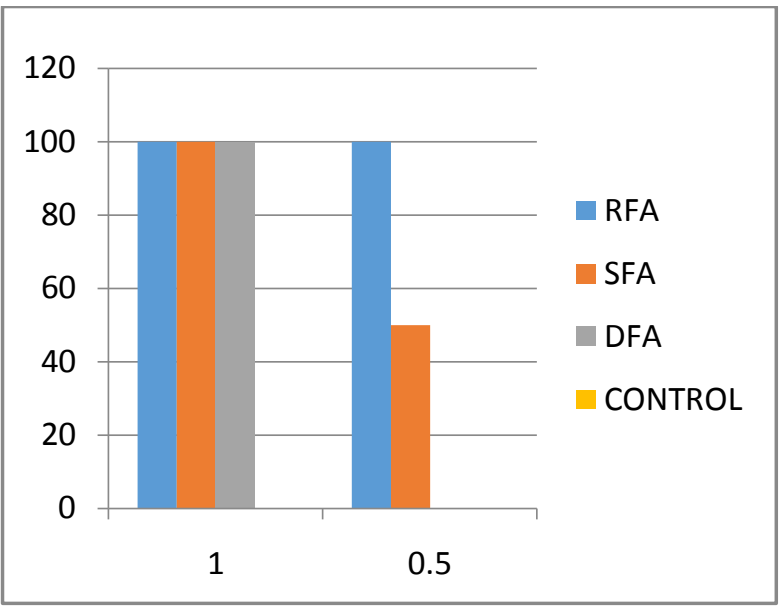

Graph-1: Isolation of PSMs using spread plate method

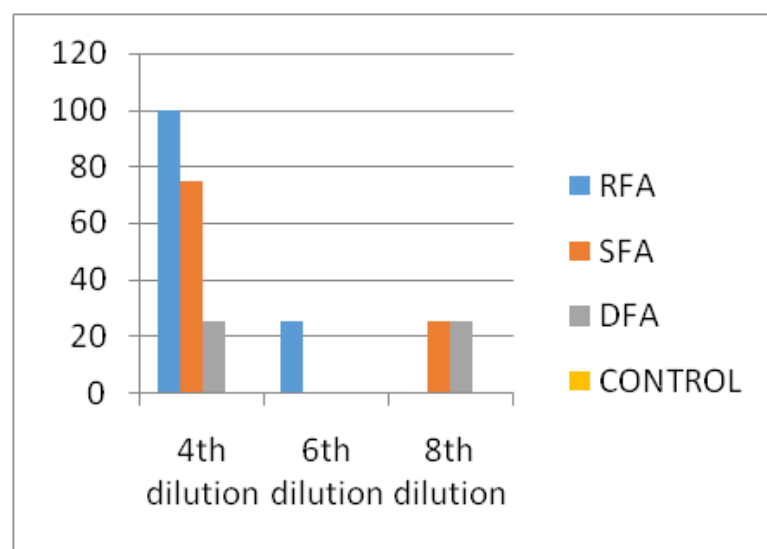

Graph -2: Isolation of PSMs using serial dilution method

The colony morphology of all the colonies sighted, in both the NBRIP and MPM, is exhibited below in Table-3 and Table-4.

\section{TABLE-3: COLONY MORPHOLOGY OF OBSERVED COLONIES OBTAINED THROUGH SPREAD PLATE TECHNIQUE.}

\begin{tabular}{|c|c|l|l|l|c|c|}
\hline S.NO & $\begin{array}{c}\text { Amount of } \\
\text { supernatant } \\
\text { added } \\
\text { (milliliter) }\end{array}$ & \multicolumn{2}{|c|}{ RFA } & DFA & Control \\
\hline 1. & 1 & $\begin{array}{l}\text { Halo } \\
\text { forming } \\
\text { colonies }\end{array}$ & $\begin{array}{l}\text { 3 single white isolated } \\
\text { colonies, shiny in } \\
\text { appearance (forms a } \\
\text { prominent "halo") }\end{array}$ & $\begin{array}{l}\text { 1 Single white isolated } \\
\text { colonies, shiny in } \\
\text { appearance (forms a } \\
\text { prominent "halo" } \\
\text { zone) }\end{array}$ & NG & NG \\
\hline 2. & 0.5 & $\begin{array}{l}\text { Halo } \\
\text { forming } \\
\text { colonies }\end{array}$ & $\begin{array}{l}\text { Single white isolated } \\
\text { colonies, shiny in } \\
\text { appearance (forms a } \\
\text { prominent "halo" zone) } \\
\text { - comparatively more } \\
\text { in number zone) }\end{array}$ & NG & NG & NG \\
\hline
\end{tabular}

TABLE-4: COLONY MORPHOLOGY OF OBSERVED COLONIES OBTAINED THROUGH SERIAL DILUTION METHOD

\begin{tabular}{|c|c|l|l|l|c|c|}
\hline S.NO & $\begin{array}{l}\text { Power of } \\
\text { Dilution }\end{array}$ & \multicolumn{2}{|c|}{ RFA } & \multicolumn{1}{c|}{ SFA } & DFA & Control \\
\hline 1. & $10^{-4}$ & $\begin{array}{l}\text { Halo } \\
\text { forming } \\
\text { colonies }\end{array}$ & $\begin{array}{l}\text { Halo forming } \\
\text { colonies } \\
\text { (dense } \\
\text { growth) }\end{array}$ & $\begin{array}{l}\text { Single isolated halo } \\
\text { forming colony found in } \\
\text { one corner of the culture } \\
\text { plate. }\end{array}$ & $\begin{array}{l}\text { 2 small } \\
\text { isolated } \\
\text { colonies in the } \\
\text { corner }\end{array}$ & NG \\
\hline 2. & $10^{-6}$ & $\begin{array}{l}\text { Halo } \\
\text { forming } \\
\text { colonies }\end{array}$ & NG & NG & NG & NG \\
\hline 3. & $10^{-8}$ & $\begin{array}{l}\text { Halo } \\
\text { forming } \\
\text { colonies }\end{array}$ & NG & NG & NG & NG \\
\hline
\end{tabular}

\section{Figures and Charts}

The PSM colonies isolated from the medium after $72 \mathrm{~h}$ of incubation time are shown below in the underlying figures: 
International Advanced Research Journal in Science, Engineering and Technology

Vol. 3, Issue 1, January 2016

\section{DFA}

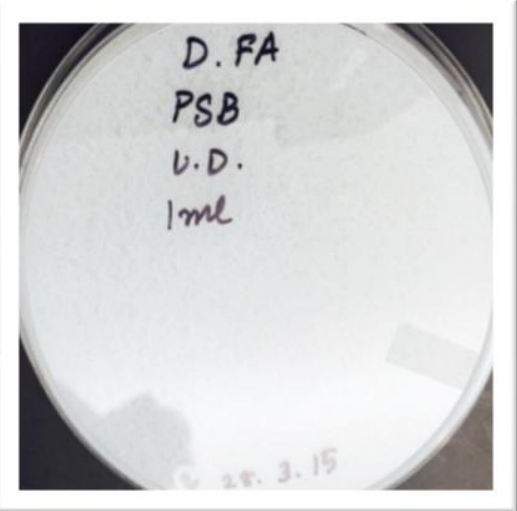

Fig-1: Lower side of the DFA plate

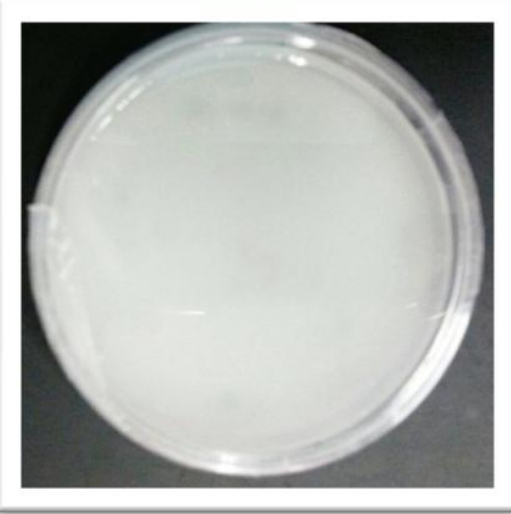

Fig-2: Upper side of the DFA plate

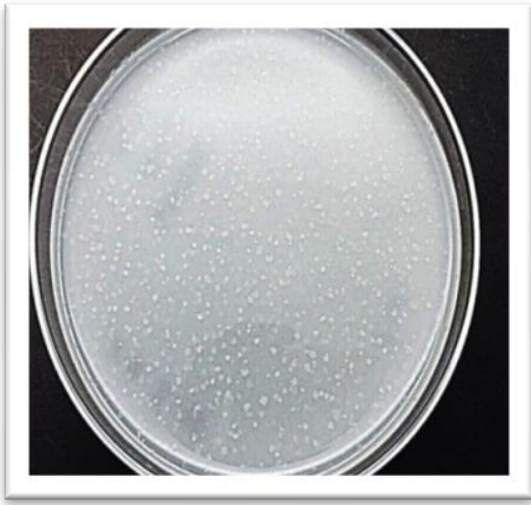

Fig-3: Uncovered DFA culture plate

SFA

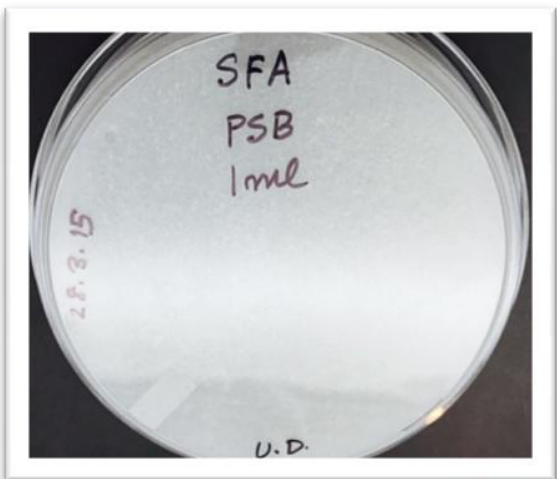

Fig-4: Lower side of SFA plate

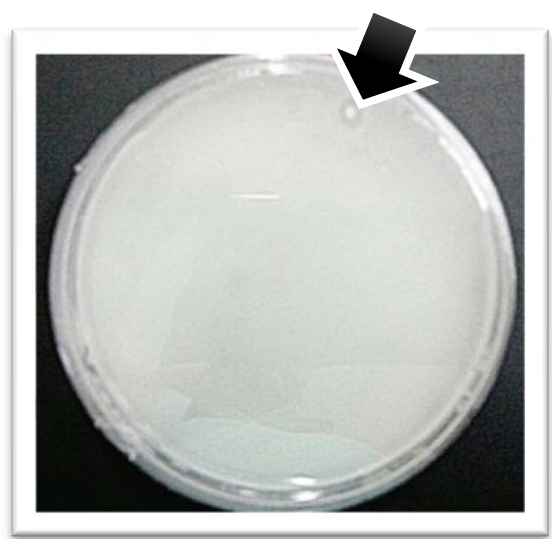

Fig-5: Upper side of SFA plate

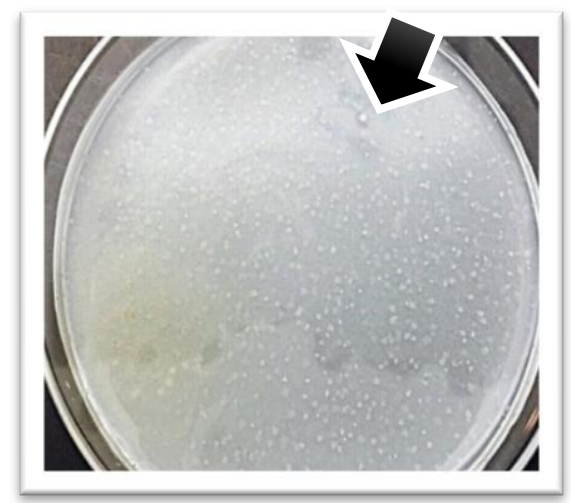

Fig-6: Uncovered SFA culture plate showing 1 halo-zone forming colony

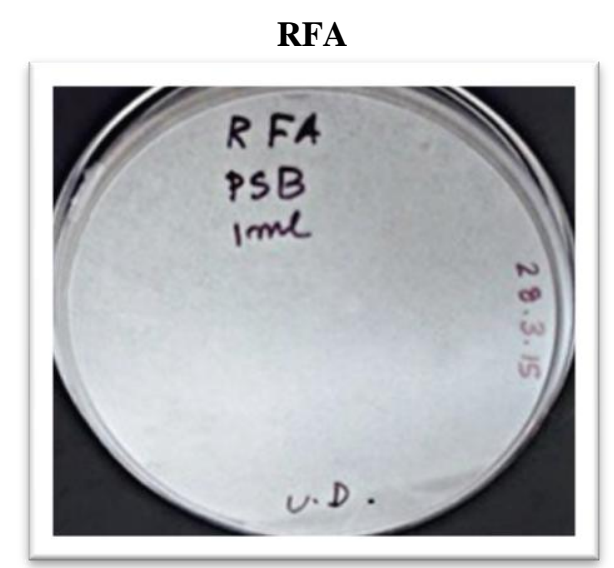

Fig-7: Lower side of RFA plate

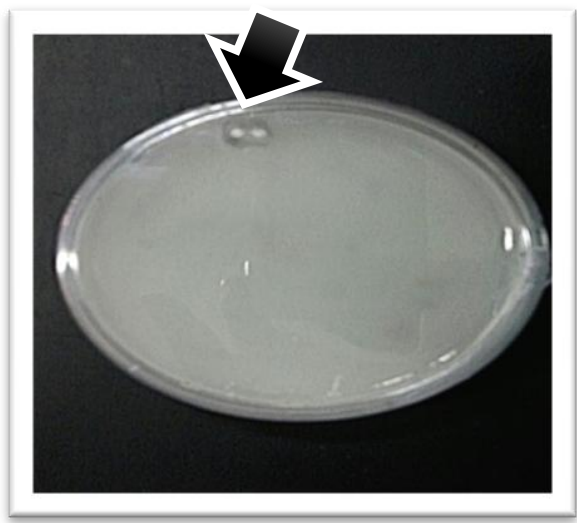

Fig-8: Upper side of RFA plate 


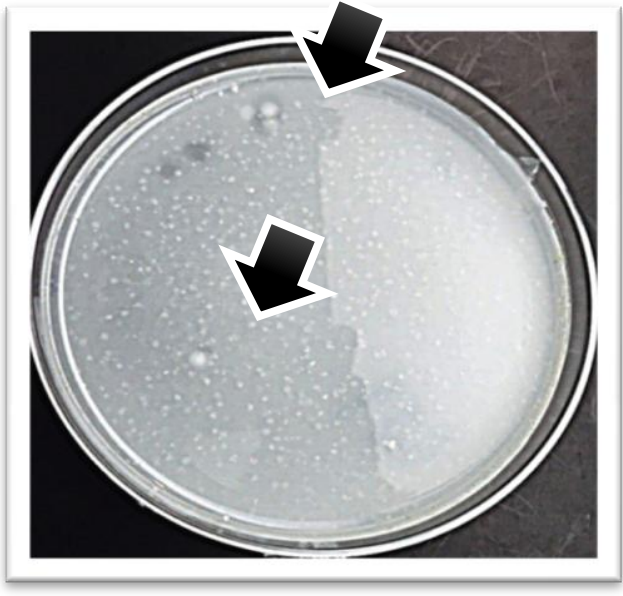

Fig-9: Uncovered RFA culture plate showing 3 halo-zone forming colony

\section{Comparison of $p H$}

The $\mathrm{pH}$ of the supernatant of each type of FA, tested after a $72 \mathrm{~h}$ subculture is cited in Table- 5 below:

TABLE - 5: COMPARATIVE ANALYSIS OF PH AMONG THE 3 DIFFERENT SAMPLES OF FA

\begin{tabular}{|l|l|l|l|l|l|}
\hline S.No & pH & DFA & SFA & RFA & Control \\
\hline 1. & $\begin{array}{l}\text { Elico pH } \\
\text { meter }\end{array}$ & 5.18 & 3.90 & 3.45 & 5.26 \\
\hline
\end{tabular}

\section{E. Gram Staining}

Upon Gram-staining the pink colonies shows gram negative characteristic of the bacterial colony, while the purple colonies confirms the presence of a gram positive strain.

In our present study transparent colonies forming a clear halo, were gram negative in character.

The milky white irregularly shaped or round shaped colonies, forming a clear halo zone around them, were a gram positive strain.

\section{CONCLUSION}

Out of all the 3 Samples of Dry Fly Ash (DFA), Settled Fly Ash (SFA) and Reclaimed Fly Ash (RFA), colony growth was observed in all the RFA, SFA and DFA plates, though in a descending fashion as follows:

Colonies in RFA > Colonies in SFA > Colonies in DFA

Most of the "halo" forming PSMs was found to be colorless colonies which did not produce any pigment. The cells observed under the microscope later, showed they were rod shaped and further on the basis of biochemical reactions was found to be Pseudomonas fluorescens. The other halo forming isolate spotted, appeared to be slimy and had milky white colored colonies with irregular or round margins. Later this isolate was identified as Bacillus megaterium on the basis of biochemical reactions. These results bore a similarity to reference [39] where similar gram negative milky white colonies were observed advertising a rod shape. The $\mathrm{pH}$ of the medium however, showed a steady decline with the increase in colony count, thereby exhibiting an indirect proportionality with the growth count.

This can be accounted to the release of organic acids namely: citric acid, gluconic acid, lactic acid, succinic acid, propionic acid etc, and organic acids from the cultures of these isolates associated with the increase in Psolubilizing activity of these strains over time [40] Thus an inverse relationship between $\mathrm{pH}$ and $\mathrm{P}$ solubilized was apparent from this study.

Also, the Reclaimed Fly Ash zone showed better microbial growth and phosphorus solubilizing ability. The years of colonization of plant species upon the RFA bed as well as the continual succession of floral species upon it, can be a major justification of this phenomenon, suggesting further that the site is moving towards eco-restoration. This affirms the usability of FA in agriculture and in soil amendment programs, as the presence of elemental phosphorus concocted with other vital mineral composition, makes FA utilization ideal for agro-forestry and crop rotation.

\section{ACKNOWLEDGEMENT}

The authors are deeply grateful to Prof. Dr. Abhijit Mitra and to Mr. Ashok Verma, Deputy Chief Engineer, DVC, M.T.P.S for their unfaltering and zestful support in the matter. The authors also extend their earnest gratitude to the other staff members, the Biotech laboratory of Techno India University, and to all the participating members who directly or indirectly contributed towards making this venture a success.

\section{REFERENCES}

[1] Basu, Manisha, et al. "Potential fly-ash utilization in agriculture: a global review." Progress in Natural Science 19.10 (2009): 1173-1186.

[2] Theis, Thomas L., and John L. Wirth. "Sorptive behavior of trace metals on fly ash in aqueous systems." Environmental Science \& Technology 11.12 (1977): 1096-1100.

[3] Plaxton, William C. "Plant response to stress: biochemical adaptations to phosphate deficiency." Encyclopedia of plant and crop science. Marcel Dekker, New York (2004): 976-980..

[4] Frydenvang, Jens, et al. "Sensitive detection of phosphorus deficiency in plants using chlorophyll a fluorescence." Plant physiology 169.1 (2015): 353-361..

[5] Rodríguez, Hilda, and Reynaldo Fraga. "Phosphate solubilizing bacteria and their role in plant growth promotion." Biotechnology advances 17.4 (1999): 319-339.

[6] Suslow, T. V. "Role of root-colonizing bacteria in plant growth." (1982).

[7] Davison, John. "Plant beneficial bacteria." Nature Biotechnology 6.3 (1988): 282-286.

[8] Lemanceau, P. "Effets bénéfiques de rhizobactéries sur les plantes: exemple des Pseudomonas spp fluorescents." Agronomie 12.6 (1992): 413-437..

[9] Pırlak, Lütfi, and Murat Köse. "Effects of plant growth promoting rhizobacteria on yield and some fruit properties of strawberry." Journal of plant nutrition32.7 (2009): 1173-1184.

[10] Glick, Bernard R. "The enhancement of plant growth by free-living bacteria."Canadian Journal of Microbiology 41.2 (1995): 109-117.

[11] Nagar, ADIT Campus New VV. "ISOLATION AND CHARACTERIZATION OF PHOSPHATE SOLUBLIZING BACTERIA FROM ANAND AGRICULTURE SOIL." Life 50: 256.

[12] Young, Chiu-Chung. Selection and application of biofertilizers in Taiwan. ASPAC Food \& Fertilizer Technology Center, 1994.

[13] Gull, M., et al. "Phosphorus uptake and growth promotion of chickpea by co-inoculation of mineral phosphate solubilising 
bacteria and a mixed rhizobial culture." Animal Production Science 44.6 (2004): 623-628.

[14] Kloepper, Joseph W., and Milton N. Schroth. "Plant growthpromoting rhizobacteria on radishes." Proceedings of the 4th international conference on plant pathogenic bacteria. Vol. 2. 1978.

[15] Goldstein, Alan H. "Bacterial solubilization of mineral phosphates: historical perspective and future prospects." American Journal of Alternative Agriculture1.02 (1986): 51-57

[16] Goldstein, Alan H. "Recent progress in understanding the molecular genetics and biochemistry of calcium phosphate solubilization by gram negative bacteria." Biological Agriculture \& Horticulture 12.2 (1995): 185-193.

[17] Duff, R. B., and D. M. Webley. "2-Ketogluconic acid as a natural chelator produced by soil bacteria." Chemistry and industry (1959): 1376-1377.

[18] Salih, H. M., et al. "Availability of phosphorus in a calcareous soil treated with rock phosphate or superphosphate as affected by phosphate-dissolving fungi." Plant and Soil 120.2 (1989): 181-185.

[19] Banik, S., and B. K. Dey. "Available phosphate content of an alluvial soil as influenced by inoculation of some isolated phosphate-solubilizing micro-organisms." Plant and Soil 69.3 (1982): 353-364.

[20] Rodríguez, Hilda, and Reynaldo Fraga. "Phosphate solubilizing bacteria and their role in plant growth promotion." Biotechnology advances 17.4 (1999): 319-339.

[21] Sperber, Joan I. "The incidence of apatite-solubilizing organisms in the rhizosphere and soil." Crop and Pasture Science 9.6 (1958): 778-781.

[22] Rudolfs, Willem. "INFLUENCE OF SULFUR OXIDATION UPON GROWTH OF SOY BEANS AND ITS EFFECT ON BACTERIAL FLORA OF SOIL." Soil Science 14.4 (1922): 247-264.

[23] Hopkins, Cyril George, and Albert Lemuel Whiting. Soil bacteria and phosphates. No. 190. University of Illinois Agricultural Experiment Station, 1916

[24] Ehrlich, H. L. "Mikrobiologische und biochemische Verfahrenstechnik."Geomicrobiology, 2nd ed. Weinheim: VCH Verlagsgesellschaft (1990).

[25] Thomas, George V., M. V. Shantaram, and N. Saraswathy. "Occurrence and activity of phosphate-solubilizing fungi from coconut plantation soils." Plant and Soil 87.3 (1985): 357-364.

[26] Asea, P. E. A., R. M. N. Kucey, and J. W. B. Stewart. "Inorganic phosphate solubilization by two Penicillium species in solution culture and soil." Soil Biology and Biochemistry 20.4 (1988): 459-464.

[27] Gupta, Dharmendra K., et al. "Impacts of fly-ash on soil and plant responses." Journal of Plant Research 115.6 (2002): 401-409.

[28] Kishor, Prem, A. K. Ghosh, and Dileep Kumar. "Use of flyash in agriculture: A way to improve soil fertility and its productivity." Asian J. Agric. Res 4.1 (2010): 1-14..

[29] Kausar, S. Studies on the effect of air pollutants and seed gall nematode Anguina tritici on wheat. Diss. PhD thesis, Aligarh Muslim University, Aligarh, India, 2007.

[30] Buddhe, Suhas Tejram, Mahendra Thakre, and Pramod R. Chaudhari. "Effect of fly ash based soil conditioner (Biosil) and Recommended Dose of Fertilizer on Soil properties, growth and yield of wheat." American J Engineering Research (AJER) 3.1 (2014): 185-199.

[31] Illmer, P., and F. Schinner. "Solubilization of inorganic phosphates by microorganisms isolated from forest soils." Soil Biology and Biochemistry24.4 (1992): 389-395.

[32] Park, Jin Hee, et al. "Isolation of phosphate solubilizing bacteria and their potential for lead immobilization in soil." Journal of Hazardous Materials 185.2 (2011): 829-836.

[33] ParkAB, Jinhee. "Enhancing the solubility of insoluble phosphorus compounds by phosphate solubilizing bacteria." (2010).

[34] Goenadi, Didiek H., and Yudho Sugiarto. "Bioactivation of poorly soluble phosphate rocks with a phosphorus-solubilizing fungus." Soil Science Society of America Journal 64.3 (2000): 927-932.

[35] Vishnoi, Gargi, Tara C. Goel, and P. K. C. Pillai. "pH optrode for the complete working range." Photonics East (ISAM, VVDC, IEMB). International Society for Optics and Photonics, 1999.

[36] Claus, D. "A standardized Gram staining procedure." World journal of Microbiology and Biotechnology 8.4 (1992): 451-452.

[37] Gandhi, A., G. Muralidharan, and E. Sudhakar. "Isolation and identification of elite phosphate solubilizing bacteria from soil under paddy cultivation."International Letters of Natural Sciences 11.1 (2014)

[38] Sharma, Kanika. Manual of Microbiology. Ane Books Pvt Ltd, 2007.
[39] Sharma, K., et al. "Effect of phosphate solubilizing bacteria on the germination of Cicer arietinum seeds and seedling growth." Journal of Herbal Medicine and Toxicology 1.1 (2007): 61-63

40] Chen, Y. P., et al. "Phosphate solubilizing bacteria from subtropical soil and their tricalcium phosphate solubilizing abilities." Applied soil ecology 34.1 (2006): 33-41

\section{BIOGRAPHIES}

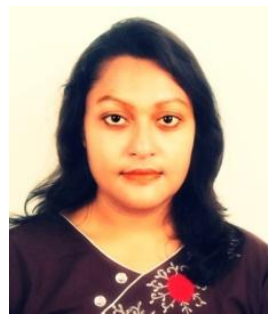

Upasana Datta was born in West Bengal, India on October 24, 1989. Upasana Datta graduated from Department of Biotechnology at University of Burdwan in 2011. Her master degree is from Department of Genetic Engineering at Maulana Abdul Kalam Azad University of Technology, West Bengal, in 2013. She has worked as a project assistant of Cancer Genomics at IIT Kharagpur, and as an on-field researcher at forest department, DVC, MTPS since 2010. She is a Ph.D student in Oceanography at Techno India University. She has conducted several projects on forestry, biodiversity and on cancer genomics. She is credited to have publications on International journals of repute and has attended several National and International seminars. Ms Datta has taught courses of Microbiology, Genetic engineering and Environmental Biotechnology and was honoured with the Young Scientist Award in 2014 by the Centre for Ocean and Environmental Studies (COES), New Delhi, India.

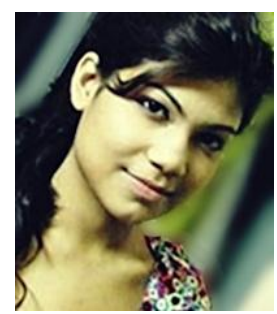

Bishakha Mondal was born in Howrah West Bengal in July 7, 1993. Bishakha Mondal is presently doing B. Tech in Biotechnology (2013-2017) from Techno India University Kolkata. She has completed her internship in microbiology from B.K.Roy Research Centre. She has attained a National seminar on 'Discovery of first test tube baby in India, 2015'. Ms Mondal has also presented posters and has conducted 2 projects on herbal products and health benefits. Currently, she has designed a "bio-abir", which is a herbal cosmetic product widely used in India.

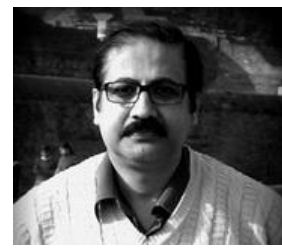

Dr. Abhijit Mitra, Associate Professor and former Head, Dept. of Marine Science, University of Calcutta (INDIA) has been active in the sphere of Oceanography since 1985. He is a Gold Medalist in Marine Science (M.Sc.) and obtained his Ph. D as NET qualified scholar in 1994. Dr. Mitra is credited to have about 350 scientific publications in various National and International journals, and 28 books of postgraduate standards. Dr. Mitra also successfully guided $24 \mathrm{Ph} . \mathrm{D}$ students. Presently his research areas include environmental science, mangrove ecology, sustainable aquaculture, alternative livelihood, climate change and carbon sequestration. 